\title{
PENGGUNAAN MODEL DISCOVERY LEARNING BERBASIS MEDIA INTERAKTIF TERHADAP KEMAMPUAN BERPIKIR KREATIF SISWA DALAM BELAJAR MATEMATIKA
}

\author{
Nurhayati ${ }^{1}$, Rahmi Wahyuni ${ }^{1}$ \\ ${ }^{1}$ Universitas Almuslim, jalan Tengku Abdurrahman No 37, Matangglumpangdua Bireuen 24411, Indonesia \\ Email: nurhayati09.nur@gmail.com \\ Email: rahmirusli@gmail.com
}

\begin{abstract}
Abstrak
Kemampuan berpikir kreatif dalam menyelesaika suatu masalah dan menemukan konsep-konsep dalam pembelajaran matematika sangat penting. Salah satu model pemebelajaran yang dianggap mampu dalam meningkatkan keterampilan berpikir kreatif adalah model pembelajaran Discovery Learning berbasis media interaktif. Penelitian ini dilakukan untuk mengetahui apakah terdapat perbedaan kemampuan berpikir kreatif siswa yang diajarkan dengan menggunakan model pembelajaran Discovery Learning berbasis media interaktif dan yang diajarkan dengan menggunakan model pembelajaran konvensional. Penelitian ini merupakan penelitian eksperimen dengan desain rancangan yaitu desain kelompok pretest-postest. Populasi penelitian ini adalah seluruh siswa kelas XI yang terdiri dari 3 kelas berjumlah 90 orang. Sampel dalam penelitian ini adalah siswa kelas XI-2 sebagai kelas eksperimen dan kelas XI-3 sebagai kelas kontrol. Pengumpulan data dilakukan dengan menggunakan tes dan selanjutnya dianalisis menggunakan Paired Samples t-test dengan bantuan program SPSS. Adapun hasil analisis data diperoleh hasil dari analisis data dengan menggunakan Paired Samples $t$-test yaitu nilai sig. (2 Tailed) adalah 0.01. Hal ini menunjukkan bahwa nilai sig. (2 Tailed) $<\alpha$ maka $H_{0}$ ditolak, artinya terdapat perbedaan kemampuan berpikir kreatif siswa dengan menggunakan model pembelajaran Discovery Learning berbasis media interaktif dan model pembelajaran konvensional pada materi barisan dan deret di MAS Darussadah Cot Tarom Bireuen.
\end{abstract}

Kata kunci: Discovery Learning, Berpikir Kreatif, Matematika.

\begin{abstract}
The ability to think creatively in solving a problem and find concepts in learning mathematics is very important. One learning model that is considered capable of enhancing creative thinking skills is the Discovery Learning model based on interactive media. This research was conducted to determine whether there are differences in students' creative thinking abilities taught by using the Discovery Learning model based on interactive media and those taught using conventional learning models. This research is an experimental research design with the design of the pretest-posttest group design. The population of this study was all students of class XI consisting of 3 classes totaling 90 people. The sample in this study were students of class XI-2 as an experimental class and class XI-3 as a control class. Data collection was performed using tests and then analyzed using Paired Samples t-test with the help of the SPSS program. The results of data analysis obtained from the data analysis using the Paired Samples t-test is the value of sig. (2 Tailed) is 0.01. This shows that the value of sig. (2 Tailed) $<\alpha$, then $H_{0}$ is rejected, meaning that there are differences in students' creative thinking abilities using the Discovery Learning model based on interactive media and conventional learning models on the row and series material in MAS Darussadah Cot Tarom Bireuen.
\end{abstract}

Keywords: Discovery Learning, Creative Thinking, Mathematics.

\section{PENDAHULUAN}

Berfikir kreatif merupakan salah satu kemampuan yang dapat dilihat dari siswa dalam proses belajar mengajar terutama dalam proses pembelajaran matematika. Matematika pada dasarkan bukan hanya mempelajari rumus saja dan mengerjakan contoh soal mengenai bagaimana rumus tersebut digunakan. Menurut Nurhayati \& Novianti (2020: 102) dalam pembelajaran matematika guru harus menyesuaikan konsep pembelajaran dan perkembangan siswa. Dalam belajar Matematika, siswa diharapkan memiliki cara pemecahan masalah yang luas sesuai dengan kemampuan berpikir kreatif mereka. Menurut Pangestu \& Yunianta (2019: 216) kemampuan berpikir kreatif dalam matematika 
diperlukan untuk memunculkan pemikiran kreatif siswa yang bertujuan membangkitkan minat siswa dan memberi kesempatan siswa dalam membuat pilihan, mengajukan pertanyaan dan memecahkan masalah yang bermakna. Dengan demikian dapat dikatakan bahwa berpikir kreatif sangat diperlukan dalam menyelesaikan persoalan yang tidak bisa diselesaikan dengan menggunakan rumus saja. Hal tersebut sejalan dengan penelitian yang dilakukan oleh Firdausi, Asikin \& Wuryanto (2018: 240) menyatakan bahwa dengan adanya kemampuan berfikir kreatif siswa mampu menguasai, memahami, dan menyelesaikan soal-soal yang rumit. Selanjutnya penelitian dari Saifuddin (2010: 38) menyatakan bahwa dalam menyelesaikan persoalan matematika dibutuhkan suatu proses pemikiran dan gagasan yang kreatif sehingga mampu merumuskan, menyelesaikan serta menafsirkan suatu masalah dalam matematika dengan baik.

Berdasarkan wawancara dengan salah satu guru matematika MAS Darussadah Tarom Bireuen, siswa mengalami kesulitan dalam menyelesaikan persoalan yang berhubungan dengan kehidupan nyata terutama pada sub materi barisan dan deret. Kebanyakan siswa hanya bisa menggunakan rumus saja sehingga ketika diberikan soal yang lebih komplek siswa akan mengalami kesulitan. Hal ini dapat dinyatakan bahwa kemampuan berpikir kreatif siswa pada sub materi tersebut belum optimal. Kemudian, berdasarkan hasil evaluasi yang dilakukan pada semester sebelumnya diperoleh hasil belajar siswa pada materi tersebut belum optimal dan nilai hasil tes kemampuan berpikir kreatif siswa diperoleh $24,70 \%$ dengan kategori tinggi, 55,60\% dengan kategori sedang dan 19,70\% dengan kategori rendah. Kemampuan siswa dalam aspek berpikir kreatif ternyata masih ada pada kategori rendah, hal ini dipengaruhi oleh beberapa hal seperti gaya belajar siswa dan guru dalam mengajar yang masih menggunakan pembelajaran konvensional.

Gaya belajar yang tidak sesuai dengan kepribadian siswa dapat mengakibatkan siswa akan mengalami kesulitan apabila menemukan soal-soal yang rumit. Menurut Nurhayati (2019:45) dalam proses pembelajaran matematika, guru harus mampu menyajikan suasana kelas yang kondusif dan melakukan inovasi yang dapat menjadikan siswa aktif. Siswa harus dijadikan sebagai subjek pembelajaran dan harus memiliki kemandirian belajar. Hal tersebut sejalan dengan pendapat yang dikemukakan oleh Wahyuni \& Nurhayati (2019: 77) guru harus mampu untuk mengolah suatu pembelajaran yang membuat siswa menjadi pribadi yang mandiri. Seorang guru harus mengetahui bagaimana gaya belajar siswa di kelas dan bagaimana kecenderungan mereka untuk menerima informasi. Guru dituntut supaya mampu menjadikan proses pembelajaran yang aktif dengan menjadikan siswa lebih dominan sehingga akan menjadikan siswa meempunyai kemampuan berpikir kreatif. Salah satu upaya yang dapat dilakukan oleh guru yaitu dengan menerapkan model pembelajaran yang tepat dan memanfaatkan media pembelajaran interaktif.

Model pembelajaran yang dianggap mampu mengembangkan kemampuan siswa berpikir kreatif adalah dengan menggunakan model pembelajaran Discovery Learning berbasis media interaktif. Pembelajaran Discovery Learning merupakan pembelajaran yang dapat memberikan kesempatan siswa untuk lebih aktif dalam mengkontruksi pengetahuannya sendiri melalui penemuan sehingga pengetahuan yang diperoleh merupakan suatu penemuan sendiri sesuai gaya belajarnya. Sani (dalam Salmi, 2019:2) menyatakan bahwa Discovery Learning adalah suatu konsep menemukan berdasarkan suatu informasi yang diperoleh berdasarkan pengamatan atau percobaan yang dilakukan. Menurut Kistian, Armanto \& Sudrajat (2017:4) model pembelajaran Discovery Learning adalah model pembelajaran yang didasarkan pada pendekatan kognitif dimana guru melakukan inovasi pada suasana pembelajaran sehingga siswa dapat belajar sendiri. Menurut Rahmayani (2019:60) penggunaan model Discovery Learning akan mengubah suatu proses pembelajaran yang bersifat fokus ke guru beralih ke situasi pembelajaran yang berpusat pada siswa.

Beberapa penelitian yang telah dilakukan dengan menggunakan Discovery Learning yaitu penelitian oleh Mujiati (2017:188) menyatakan bahwa metode Discovery Learning dapat 
meningkatkan hasil belajar matematika siswa pada materi konsep keliling dan luas bangun datar. Tumurun, Gusrayani, \& Jayadinata (2016:109) menyatakan bahwa pembelajaran dengan menggunakan model pembelajaran Discovery Learning lebih baik dalam meningkatkan keterampilan berpikir kreatif siswa dibandingkan dengan model pembelajaran konvensional. Selanjutnya penelitian dari Sappaile, Ba'ra, Djam'an, Kadir \& Darwis (2018:265), Rahmayani (2019: 61), Putri, Lesmono, \& Aristya (2017: 178) dan penelitian Fitriah, Murtadlo, \& Warti (2018: 112) menunjukkan bahwa model pembelajaran Discovery Learning memberikan hasil yang lebih baik dari pada model pembelajaran langsung atau konvensional. Dari beberapa penelitian tersebut belum ada yang meneliti tentang penggunaan model Discovery Learning berbasis media interaktif terhadap kemampuan berpikir kreatif siswa dalam belajar matematika khususnya pada materi barisan dan deret.

Berdasarkan permasalahan diatas, adapun tujuan dari penelitian ini yaitu untuk menyatakan apakah terdapat perbedaan kemampuan berpikir kreatif siswa yang diajarkan dengan menggunakan model pembelajaran Discovery Learning berbasis media interaktif dan yang diajarkan dengan menggunakan model pembelajaran konvensional pada materi barisan dan deret di MAS Darussadah Cot Tarom Bireuen. Adapun kegunaan penelitian ini yaitu diharapkan model pembelajaran Discovery Learning berbasis media interaktif dapat meningkatkan kemampuan berpikir kreatif siswa. Hal ini dapat dinyatakan bahwa dalam proses pembelajaran Discovery Learning berbasis media interaktif, siswa ikut terlibat secara langsung untuk memperoleh pengetahuan dan penemuannya sendiri sehingga siswa termotivasi dalam mengikuti proses belajar mengajar.

\section{METODE PENELITIAN}

Jenis penelitian ini merupakan penelitian eksperimen dengan desain rancangan yaitu desain kelompok pretest-postest. Dalam penelitian ini akan diberikan pretest dan posttest untuk kelas eksperimen dan kelas kontrol dengan menggunakan soal yang sama sebelum dan sesudah diberi perlakuan. Penelitian ini dilaksanakan di MAS Darussadah Cot Tarom kecamatan Jeumpa Kabupaten Bireuen pada semester ganjil tahun ajaran 2019/2020. Subjek penelitian ini berjumlah 90 siswa yang terdiri dari 3 kelas yaitu XI-1, XI-2, dan XI-3 dan dinyatakan sebagai populasi. Adapun penentuan sampel dalam penelitian ini dilakukan melalui teknik random sampling. Dari hasil undian didapatkan dua kelas yaitu kelas XI-2 dan XI-3. Selanjutnya akan dilakukan lagi pemilihan untuk menentukan kelas kontrol dan kelas ekperimen. Terpilihlah XI-2 sebagai kelas eksperimen dan XI-3 sebagai kelas kontrol. Instrumen yang digunakan dalam penelitian ini berupa perangkat pembelajaran seperti silabus dan sebagainya. Adapun teknik analisis data menggunakan Paired Samples t-test dengan bantuan program SPSS. Data yang dibutuhkan dalam penelitian ini adalah hasil tes siswa setelah diterapkan model pembelajaran Discovery Learning berbasis media interaktif dan model pembelajaran konvensional.

\section{HASIL PENELITIANDAN PEMBAHASAN}

Hasil analisis data menunjukkan bahwa terjadi peningkatan terhadap kemampuan berpikir kreatis siswa pada kelas eksperimen dengan rata-rata lebih baik dibandingkan kelas kontrol. Peningkatan ini dipengaruhi oleh pemanfaatan model pembelajaran Discovery Learning berbasis media interaktif, sehingga terlihat jelas pengaruhnya dibandingkan dengan kelas kontrol yang menggunakan metode konvensional dalam proses pembelajaran. Adapun hasil rekapitulasinya dapat dilihat pada Tabel 1 .

Tabel 1. Rekapitulasi Hasil Tes Siswa

\begin{tabular}{|l|c|c|}
\hline Data Statistik & Kelas Eksperimen & Kelas Kontrol \\
\hline Mean & 74.70 & 72.38 \\
\hline
\end{tabular}




\begin{tabular}{|l|c|c|}
\hline Standar Deviasi & 7.32 & 6.55 \\
\hline Variansi & 53.61 & 42.96 \\
\hline Skor Minumum & 64.34 & 60.55 \\
\hline Skor Maksimal & 85.66 & 83.77 \\
\hline Rentang & 21.32 & 23.22 \\
\hline
\end{tabular}

Berdasarkan Tabel 1 terlihat bahwa nilai rata-rata dari hasil tes siswa dengan menggunakan model pembelajaran Discovery Learning berbasis media interaktif dalam pembelajarannya adalah 74.70 sedangkan nilai rata-rata untuk hasil tes siswa dengan menggunakan model konvensional dalam pembelajarannya adalah 72.38. Dapat dikatakan bahwa nilai rata-rata dari kedua sampel ini berbeda dan jelas nilai rata-rata siswa dengan menggunakan model pembelajaran Discovery Learning berbasis media interaktif lebih besar dibanding nilai rata-rata siswa dengan menggunakan model pembelajaran konvensional. Selanjutnya, berdasarkan nilai standar deviasi dengan menggunakan model pembelajaran Discovery Learning berbasis media interaktif diperoleh 7.32 sedangkan nilai standar deviasi dengan menggunakan model konvensional diperoleh 6.55. Hal ini dapat dinyatakan bahwa hasil tes siswa dengan menggunakan model pembelajaran konvensional lebih homogen dibandingkan dengan model pembelajaran Discovery Learning berbasis media interaktif. Hal yang serupa juga terlihat dari nilai rentang untuk hasil tes siswa dengan menggunakan model pembelajaran konvensional lebih besar dibandingkan dengan hasil tes siswa dengan menggunakan model pembelajaran Discovery Learning berbasis media interaktif.

Pengujian hipotesis dalam penelitian ini akan dilakukan dengan menerapkan pengujian statistik uji-t dengan $\alpha=5 \%$, akan tetapi uji normalitas dan homogenitas akan dilakukan terlebih dahulu sebelum dilakukan pengujian hipotesis. Adapun hasil rekapitulasinya adalah sebagai berikut:

Tabel 2. Pengujian Normalitas dan Homogenitas

\begin{tabular}{|l|c|c|c|c|}
\hline \multirow{2}{*}{ Data } & \multicolumn{4}{|c|}{ Nilai Sig. Terhadap $\alpha$} \\
\cline { 2 - 4 } & Uji Normalitas & Kesimpulan & Uji Homogenitas & Kesimpulan \\
\hline Kelas Eksperimen & $0.33>0.05$ & \multirow{2}{*}{ Normal } & $0.06>0.05$ & \multirow{2}{*}{ Homogen } \\
\cline { 2 - 2 } Kelas Kontrol & $0.69>0.05$ & & $0.91>0.05$ & \\
\hline
\end{tabular}

Berdasarkan Tabel 2 menjelaskan bahwa hasil tes siswa pada kelas eksperimen dan kelas kontrol berdistribusi normal. Hasil analisis data kelas eksperimen diperoleh nilai sig. sebesar 0.33 dan data dari kelas kontrol diperoleh nilai sig. sebesar 0.69 atau dapat dinyatakan bahwa kedua kelas memiliki nilai sig. > 5\%. Jadi, dapat disimpulkan bahwa hasil tes siswa yang terdapat pada kelas eksperimen dan kelas kontrol sudah berdistribusi normal. Pengujian homogenitas dari hasil tes kelas eksperimen diperoleh nilai sig. sebesar 0.06 dan dari hasil tes kelas kontrol diperoleh nilai sig. sebesar 0.91 atau dapat dinyatakan bahwa kedua kelas memiliki nilai sig. > 5\%. Jadi, dapat dinyatakan bahwa hasil tes siswa yang terdapat pada kelas eksperimen dan kelas kontrol homogen. Adapun untuk hasil dalam pengujian hipotesis dengan menerapkan pengujian statistik uji-t, $\alpha=5 \%$ dapat dilihat pada Tabel 3 .

Tabel 3. Pengujian Hipotesis Paired Samples t-Test

\begin{tabular}{|c|c|c|c|c|c|c|c|}
\hline \multicolumn{8}{|c|}{ Paired Difference } \\
\hline \multirow[t]{2}{*}{ Mean } & \multirow{2}{*}{$\begin{array}{c}\text { Std. } \\
\text { Deviation }\end{array}$} & \multirow{2}{*}{$\begin{array}{c}\text { Std. Error } \\
\text { Mean }\end{array}$} & \multicolumn{2}{|c|}{$\begin{array}{c}\text { 95\% Confidence of The } \\
\text { Difference }\end{array}$} & \multirow[t]{2}{*}{$\mathrm{t}$} & \multirow[t]{2}{*}{$\mathrm{df}$} & \multirow{2}{*}{$\begin{array}{c}\text { Sig. } \\
(2 \text { Tailed })\end{array}$} \\
\hline & & & Lower & Upper & & & \\
\hline 2.70 & 5.08 & 0.97 & 4.71 & 0.69 & 2.76 & 58 & 0.01 \\
\hline
\end{tabular}


Berdasarkan Tabel 3 diperoleh hasil dari analisis data dengan menggunakan Paired Samples t-test yaitu nilai sig. (2 Tailed) adalah 0.01 . Hal ini menunjukkan bahwa nilai sig. (2 Tailed) $<\alpha$ maka $H_{0}$ ditolak, artinya terdapat perbedaan kemampuan berpikir kreatif siswa dengan menggunakan model pembelajaran Discovery Learning berbasis media interaktif dan model pembelajaran konvensional pada materi barisan dan deret di MAS Darussadah Cot Tarom Bireuen.

Dari hasil penelitian menunjukkan adanya perbedaan kemampuan berpikir kreatif siswa yang diajarkan dengan menggunakan model pembelajaran Discovery Learning berbasis media interaktif. Hasil tes siswa dengan menggunakan model pembelajaran Discovery Learning berbasis media interaktif lebih baik dari pada hasil tes siswa dengan menggunakan model pembelajaran konvensional. Hal ini dikarenakan pada model pembelajaran Discovery Learning berbasis media interaktif siswa terlibat secara aktif ketika proses pembelajaran berlangsung sehingga lebih dapat mengeksplorasi materi dan memperoleh pengetahuan dengan menemukan konsep belajarnya sendiri. Temuan ini senada dengan beberapa hasil penelitian lain yang menggunakan model pembelajaran Discovery Learning seperti penelitian dari (Mujiati, 2017); (Tumurun, Gusrayani, \& Jayadinata, 2016); (Sappaile, Ba'ra, Djam'an, Kadir \& Darwis, 2018); (Rahmayani 2019); (Putri, Lesmono, \& Aristya, 2017) dan (Fitriah, Murtadlo, \& Warti, 2018).

\section{KESIMPULAN}

Berdasarkan hasil penelitian dan pembahasan maka dapat disimpulkan bahwa terdapat perbedaan kemampuan berpikir kreatif siswa yang diajarkan dengan menggunakan model pembelajaran Discovery Learning berbasis media interaktif dan yang diajarkan dengan menggunakan model pembelajaran konvensional pada materi barisan dan deret di MAS Darussadah Cot Tarom Bireuen. Model Discovery Learning berbasis media interaktif yang digunakan guru dapat memberikan kebebasan kepada siswa dalam menemukan pengetahuannya sendiri. Hal ini dikarenakan dengan menemukan sendiri siswa dapat lebih mengerti materi secara mendalam sehingga dapat meningkatkan kemampuan berpikir kreatif siswa.

\section{REFERENCES}

Firdausi, Y. N., Asiki, M., \& Wuryanto (2019). Analisis Kemampuan Berpikir Kreatif Siswa Ditinjau dari Gaya Belajar pada Pembelajaran Model Eliciting Activities (MEA). PRISMA, 1(1), 239147.

Fitriah. Murtadlo, A., \& Warti., R. (2017). Pengaruh Model Pembelajaran Discovery Learning Terhadap Hasil Belajar Matematika Siswa MAN Model Kota Jambi. Jurnal Pelangi, 9(2), 108-112.

Kistian, A., Armanto, D., \& Sudrajat, A. (2017). The Effect of Discovery Learning Method on The Math Learning of The V SDN 18 Students of Banda Aceh, Indonesia. British Journal of Education, 5(10), 1-11.

Mujiati. (2017). Peningkatan Hasil Belajar Matematika Melalui Metode Discovery Learning pada Materi Konsep Keliling dan Luas Bangun Datar Siswa Kelas V A SD Negeri 009 Pulau Kijang Kecamatan Reteh. Jurnal Primary Program Studi Pendidikan Guru Sekolah Dasar Fakultas Keguruan dan Ilmu Pendidikan Universitas Riau, 6(1), 179-189.

Nurhayati. (2019). Pengaruh Strategi Pembelajaran Plantet Questions Terhadap Prestasi Belajar Siswa pada Materi Trigonometri di Kelas X SMAN 1 Bireuen. Jurnal Pendidikan Almuslim, 7(1), 45-49. 
Nurhayati \& Novianti. (2020). Pengaruh SPSS Terhadap Hasil Belajar pada Materi Statistika Deskriptif. AKSIOMA: Jurnal Program Studi Pendidikan Matematika, 9(1), 101-107.

Pangestu, N., S \&Yusnianta, T., N., H. (2019). Proses Berpikir Kreatif Matematis Siswa Extrovert dan Introvert SMP Kelas VIII Berdasarkan Tahapan Wallas. Mosharafa: Jurnal Pendidikan Matematika,8(2), 215-226.

Putri, R. H., Lesmono, A. D., \& Aristya, P. D. (2017). Pengaruh Model Discovery Learning terhadap Motivasi Belajar dan Hasil Belajar Fisika Siswa MAN Bondowoso. Jurnal Pembelajaran Fisika, 6(2), 173-180.

Rahmayani, A. (2019). Pengaruh Model Pembelajaran Discovery Learning dengan menggunakan Media video Terhadap hasil Belajar Siswa. Jurnal Pendidikan, 4(1), 59-62.

Salmi. (2019). Penerapan Model Pembelajaran Discovery Learning Dalam Meningkatkan Hasil Belajar Ekonomi Peserta Didik Kelas XII IPA.2 SMA Negeri 13 Palembang. Jurnal Profit, 6(1), 1-16.

Saefuddin, A., A. (2012). Pengembangan Kemampuan Berpikir Kreatif Siswa dalam Pembelajaran Matematika dengan Pendekatan Pendidikan Matematika Realitik Indonesia (PMRI). AlBidayah, 4(1), 37-48.

Sappaile, B. I., Ba'ra, Y., Djam'an, Y., Kadir., \& Darwis, M. (2018). Pengaruh Penerapan Model Pembelajaran Discovery Learning Terhadap Hasil Belajar Matematika Ditinjau dari Minat Belajar Siswa SMP Negeri di Kota Rantepao. Journal of Mathematics Education IKIP Semarang, 2(2), 253-266.

Tumurun, S. W., Gusrayani, D., \& Jayadinata (2016). Pengaruh Model Pembelajaran Discovery Learning Terhadap Keterampilan Berpikir Kreatif Siswa pada Materi Sifat - Sifat Cahaya. Jurnal Pena Ilmiah, 1(1), 101-110.

Wahyuni, R \& Nurhayati. (2019). Kemandirian Belajar Mahasiswa Melalui Blended Learning pada Mata Kuliah Matematika Ekonomi. Jurnal Ilmiah Pendidikan Matematika Al-Qalasadi, $3(2), 76-81$ 